\title{
Induction of DNA Damage in Mouse Colorectum by Administration of Colibactin-producing Escherichia coli, Isolated from a Patient With Colorectal Cancer
}

\author{
TAKUMI NARITA ${ }^{1,2}$, YUTA TSUNEMATSU ${ }^{3}$, NORIYUKI MIYOSHI ${ }^{4}$, MASAMI KOMIYA $^{2}$, \\ TAKAHIRO HAMOYA $^{1,2}$, GEN FUJII ${ }^{5}$, YUKO YOSHIKAWA ${ }^{6}$, MICHIO SATO ${ }^{3}$, MASANOBU KAWANISHI ${ }^{7}$, \\ HARUHIKO SUGIMURA $^{8}$, YUJI IWASHITA ${ }^{8}$, YUKARI TOTSUKA ${ }^{9}$, MASARU TERASAKI $^{10}$, \\ KENJI WATANABE ${ }^{3}$, KEIJI WAKABAYASHI ${ }^{11}$ and MICHIHIRO MUTOH ${ }^{1,2}$ \\ ${ }^{1}$ Department of Molecular-Targeting Prevention, Graduate School of Medical Science, \\ Kyoto Prefectural University of Medicine, Kyoto, Japan; \\ ${ }^{2}$ Epidemiology and Prevention Division, Research Center for Cancer Prevention and Screening, \\ National Cancer Center, Tokyo, Japan; \\ ${ }^{3}$ Department of Pharmaceutical Sciences, University of Shizuoka, Shizuoka, Japan; \\ ${ }^{4}$ School of Food and Nutritional Sciences, University of Shizuoka, Shizuoka, Japan; \\ ${ }^{5}$ Central Radioisotope Division, National Cancer Center Research Institute, Tokyo, Japan; \\ ${ }^{6}$ School of Veterinary Medicine, Faculty of Veterinary Science, \\ Nippon Veterinary and Life Science University, Musashino, Japan; \\ ${ }^{7}$ Graduate School of Science and Radiation Research Center, Osaka Prefecture University, Sakai, Japan; \\ ${ }^{8}$ Department of Tumor Pathology, Hamamatsu University School of Medicine, Hamamatsu, Japan; \\ ${ }^{9}$ Laboratory of Environmental Toxicology and Carcinogenesis, \\ School of Pharmacy, Nihon University, Funabashi, Japan; \\ ${ }^{10}$ School of Pharmaceutical Sciences, Health Sciences University of Hokkaido, Kanazawa, Japan; \\ ${ }^{11}$ Graduate Division of Nutritional and Environmental Sciences, University of Shizuoka, Shizuoka, Japan
}

\begin{abstract}
Background/Aim: Among colorectal cancerassociated intestinal microbiota, colibactin-producing $\left(\mathrm{clb}^{+}\right)$ bacteria are attracting attention. We aimed to clarify the interaction between $\mathrm{clb}^{+}$Escherichia coli and normal colorectal epithelial cells in vivo and in vitro. Materials and Methods: Five-week-old female Balb/c mice were divided in an untreated group, a group treated with $\mathrm{clb}^{+} E$. coli isolated from a Japanese patient with colorectal cancer (E. coli-50), and a group treated with non colibactin-producing E. coli (E. coli-50/AclbP). Mice were sacrificed at 18 weeks of treatment. Results: Treatment with $\mathrm{clb}^{+} E$. coli increased positivity for H2A histone family member X phosphorylated
\end{abstract}

This article is freely accessible online.

Correspondence to: Michihiro Mutoh, 465 Kajii-cho, KawaramachiHirokoji, Kamigyo-ku, Kyoto, 602-8566, Japan. Tel: +81 752515339, Fax: +81 752410792, e-mail: mimutoh@koto.kpu-m.ac.jp

Key Words: Colibactin, colorectal cancer, DNA damage, $\gamma \mathrm{H} 2 \mathrm{AX}-$ positive cells, mouse. at Ser-139 $(\gamma H 2 A X)$ in epithelial cells of the luminal surface of the mouse rectum but this did not occur in the E. coli$50 / \Delta c l b P$ and untreated groups. In an in vitro setting, the ratio of apoptotic cells was increased and cell counts were reduced by treatment with $\mathrm{clb}^{+} E$. coli more than in untreated cells and normal rat colorectal epithelial cells. Conclusion: E. coli-50 induced DNA damage in the mouse rectum, possibly by direct interaction between $\mathrm{clb}^{+} E$. coli and normal colorectal epithelial cells. Our findings imply that regulation of $\mathrm{clb}^{+} E$. coli infection may be a useful strategy for colorectal cancer control.

It is well known that diet strongly affects the incidence of colorectal cancer (1). As suggested from fecal and colonic mucosa of healthy individuals, a poor diet results in potentially adverse intestinal microbiota profiles $(2,3)$. Recently, it was found that intestinal microbiota are involved in changes in physical condition and the development of diseases. It has been clarified that the intestinal microbiota may change at a very early step of colorectal carcinogenesis (4). Atopobium parvulum and Actinomyces odontolyticus have been identified as bacteria that are elevated only in 
patients with multiple polyps (adenoma) and intramucosal cancer (4). Thus, it is strongly suggested that these bacteria are related to the early stage of colorectal cancer. Fusobacterium nucleatum and Peptostreptococcus stomatis are bacteria that increase from the stage of intramucosal cancer and increase as the disease progresses (4). These bacteria have already been reported to be elevated in advanced colorectal cancer. It is interesting to clarify the relation between diet and such a specific bacterial increase in detail. Moreover, it is interesting to clarify the mechanism of how such bacteria might induce colorectal cancer.

Recently, colibactin-producing bacteria are attracting attention because they may contribute to colorectal carcinogenesis $(5,6)$. This bacterium is interesting because it may not be transmitted through food intake but rather from mother to infant by intimate contact, such as natural childbirth and breastfeeding (7). Colibactin is a gut bacterial genotoxin that is suggested to be linked to the development of colorectal cancer. Colibactin is produced by several bacteria, especially by Enterobacteriaceae, including certain Escherichia coli strains, those harbored in the human intestine. Colibactin is a hybrid non-ribosomal peptide-polyketide, synthesized by multi-enzyme complexes encoded by genes carried on the 54$\mathrm{kb}$ genomic region ( $p k s$ island) of $E$. coli (8). Exposure to $E$. coli containing the $p k s$ island causes DNA double-strand breaks in human cells and animals, and accelerates colonic tumor growth under conditions of host inflammation (9-11). However, the underlying molecular mechanisms that induce mutagenesis/carcinogenesis have not fully revealed yet. This is largely due to a lack of research clarifying the structure of colibactin. Of note, we recently successfully identified colibactin metabolites with the rearranged form of an intact colibactin (12).

To our knowledge, data on the effects of colibactin exposure in in vitro and in vivo settings are limited. A previous study showed that colibactin alkylated DNA in germ-free C57BL/6J mice (13). DNA alkylation is considered one of the pivotal factors in carcinogenesis. Recently, we isolated various colibactin-producing $\left(\mathrm{clb}^{+}\right) \mathrm{E}$. coli strains, and found that E. coli-50, from a Japanese patient with colorectal cancer, producing a high amount of colibactin, showed strong genotoxicity in in vitro assays (1417). Thus, we used this strain for an experiment to determine the effects of $\mathrm{clb}^{+} E$. coli on rodent colorectal mucosa epithelial cells in vivo and in vitro, revealing that $c l b^{+} E$. coli-50 induces DNA damage on the surface mucosa of mouse epithelial cells, possibly by direct interaction between $c l b^{+}$E. coli and normal colorectal epithelial cells.

\section{Materials and Methods}

E. coli strains. Isolation of E. coli-50 from the colorectal cancer specimen was reported elsewhere (14). An E. coli-50/ $\Delta$ clbP strain that was deficient in producing colibactin owing to a disruption of the $c l b P$ gene was established as described elsewhere (12).

Animals and animal experiment. Four-week-old female Balb/c mice were purchased from Japan SLC (Hamamatsu, Japan). The mice were housed in plastic cages with sterilized softwood chips as bedding in a barrier-sustained animal room maintained at $24 \pm 2^{\circ} \mathrm{C}$ and $55 \%$ humidity under a $12 \mathrm{~h}$ light/dark cycle. After 1 week adaptation, mice were randomized by body weight into control $(\mathrm{n}=5)$, E. coli-50 $(\mathrm{n}=5)$ or E. coli-50/ $\Delta$ clbP $(\mathrm{n}=5)$ groups. Each $E$. coli strain was cultured overnight in LB medium $(0.5 \mathrm{ml})$ and suspended in drinking water $(100 \mathrm{ml})$ at a concentration of $5 \times 10^{8}$ cells $/ \mathrm{ml}$, which was prepared every 2-3 days, and given to mice for 18 weeks. Standard chow (AIN-93M; Oriental Yeast, Tokyo, Japan) and water were available ad libitum. The animals were observed daily for clinical symptoms and mortality. Body weight and food consumption were measured every 2-3 days.

At the time of sacrifice, the mice were anesthetized, and blood released from their abdominal veins. Their colorectum was removed, opened longitudinally and fixed flat between sheets of filter paper in $10 \%$ buffered formalin. The colorectum was divided into the rectum ( $1 \mathrm{~cm}$ in length), and the remaining segments divided into proximal, middle and distal parts, and used for later immunochemical staining. All experiments were performed according to the Guidelines for Animal Experiments in the University of Shizuoka and were approved by the Institutional Ethics Review Committee for Animal Experimentation of the University of Shizuoka (\#175175). The animal protocol was designed to minimize pain and discomfort to the animals. All animals were euthanized for tissue collection by isoflurane overdose.

Cell culture. Rat primary colorectal epithelial cells (PriA/MUTO2 cells) were derived from a 4-week-old F344 rat. In brief, the colorectum was removed and treated with Dispase I (Merck KGaA, Darmstadt, Germany) for $30 \mathrm{~min}, 37^{\circ} \mathrm{C}$ and the luminal side of the colorectum scraped to obtain intact crypts. Crypts were cultured in a collagen-coated dish. Cells showing a cobblestone pattern of growth were further cultured. PriA/MUTO2 cells were maintained in RPMI 1640 (Nacalai Tesque Inc., Kyoto, Japan) supplemented with $10 \%$ heat-inactivated fetal bovine serum and antibiotics (100 $\mu \mathrm{g} / \mathrm{ml}$ streptomycin and $100 \mathrm{U} / \mathrm{ml}$ penicillin; Nacalai Tesque Inc.) at $37^{\circ} \mathrm{C}$ in $5 \% \mathrm{CO}_{2}$.

Immunohistochemical staining. Mouse intestines were fixed, embedded, and sectioned for further immunohistochemical examination using the avidin-biotin complex immunoperoxidase technique after heating with $10 \mathrm{mM}$ citrate buffer $(\mathrm{pH}$ 6.0). The primary antibody was anti-H2A histone family member $\mathrm{X}$ with phosphorylated Ser-139 ( $\gamma \mathrm{H} 2 \mathrm{AX}$ ) (Cell Signaling Technology, Danvers, MA, USA) at $100 \times$ dilution. As the secondary antibody, biotinylated horse anti-mouse IgG (Vector Laboratories, Burlingame, CA, USA) was used at $200 \times$ dilution. Staining was undertaken using avidin-biotin reagents (Vectastain $\mathrm{ABC}$ reagents; Vector Laboratories), 3,3'-diaminobenzidine, and hydrogen peroxide, and the sections were counterstained with hematoxylin to facilitate orientation. As a negative control, consecutive sections were immunostained without exposure to the primary antibody. The ratio of $\gamma \mathrm{H} 2 \mathrm{AX}$-positive cells was calculated by the formula: $100 \times$ number of $\gamma \mathrm{H} 2 \mathrm{AX}$-positive cells/total number of cells in the intestine (at 100× magnification). 
A

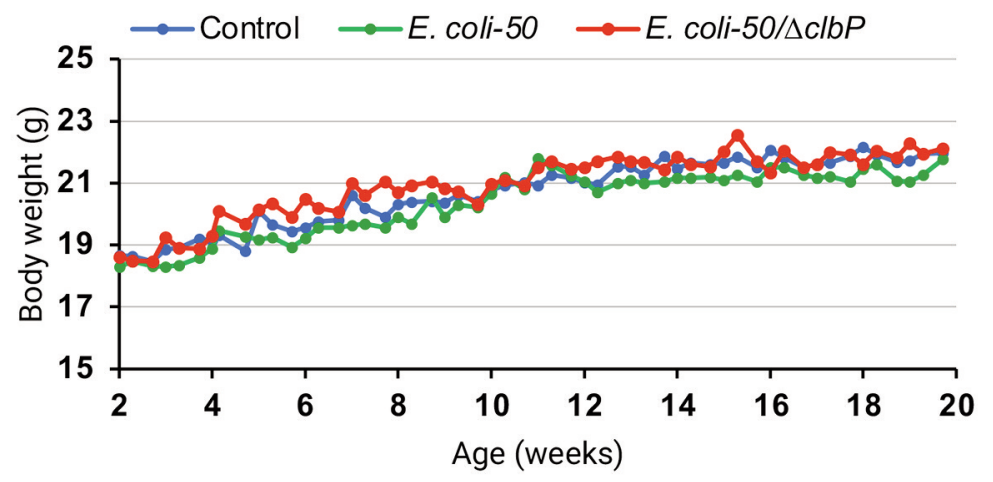

B

Control

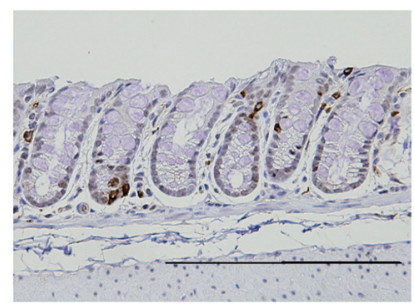

E. coli-50

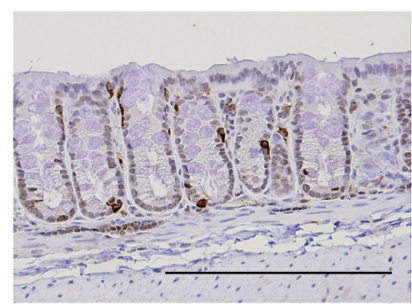

E. coli-50/ $\Delta c / b P$

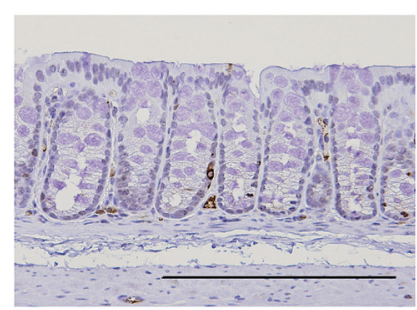

C

Rectum

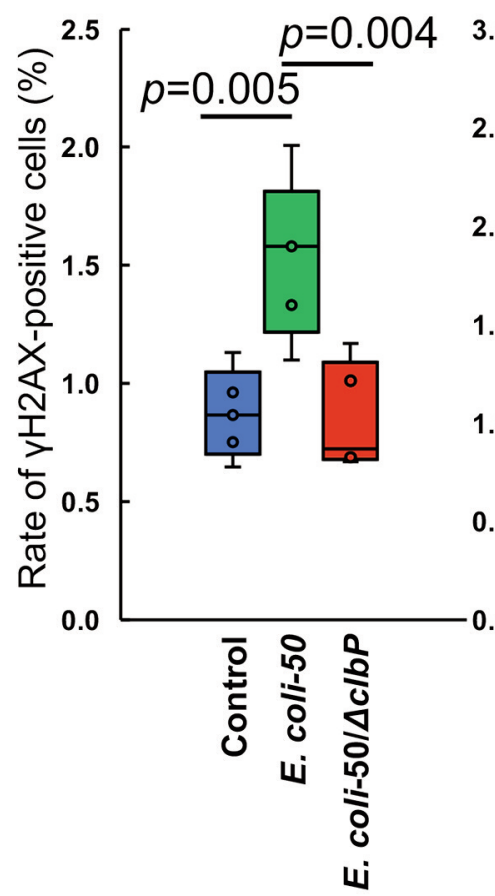

Distal

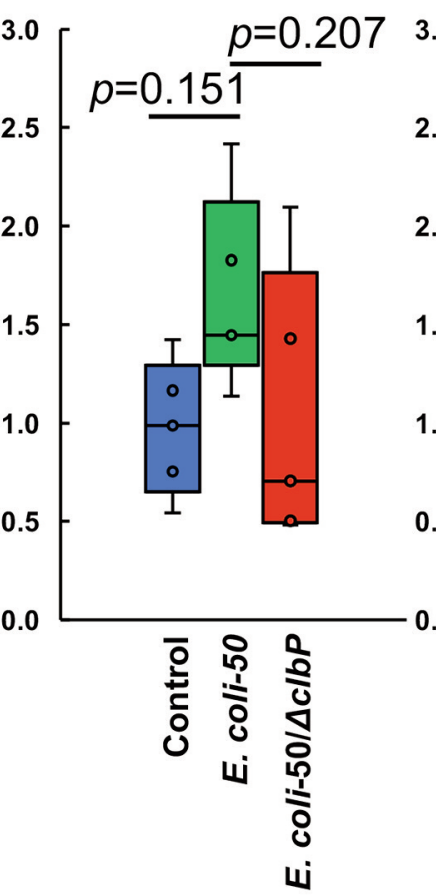

Middle

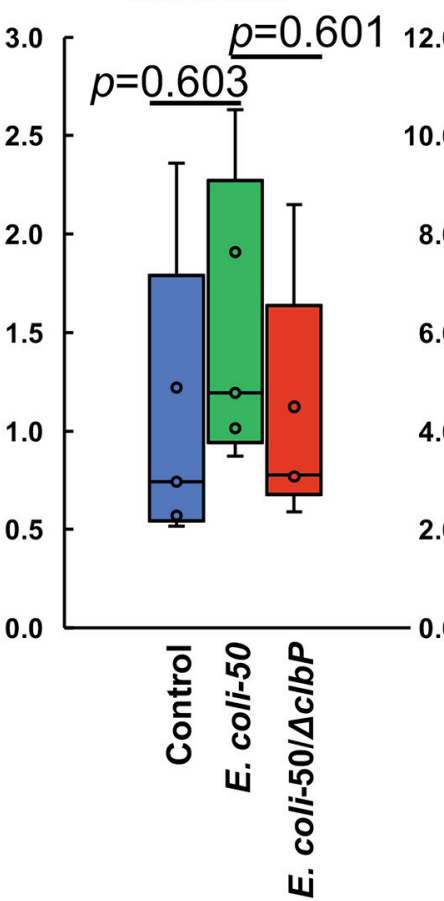

Proximal

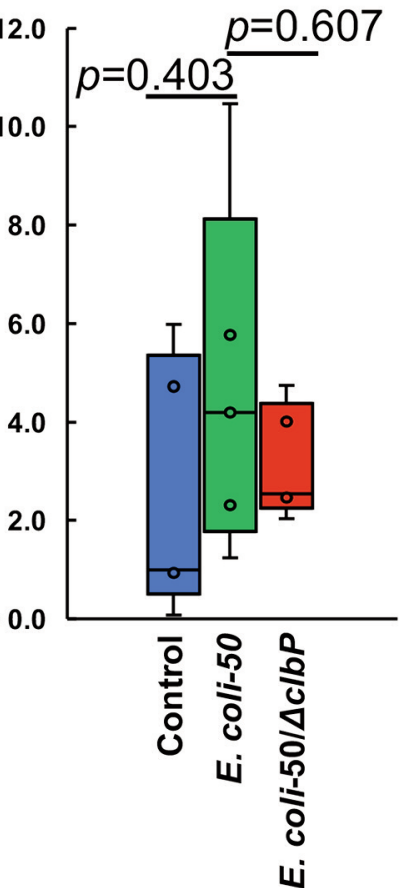

Figure 1. Effects of colibactin on DNA damage of the intestines in mice. A: Balb/c mice were treated with $\mathrm{clb}^{+}$Escherichia coli isolated from a Japanese patient with colorectal cancer (E. coli-50) or with non colibactin-producing E. coli (E. coli-50/AclbP) at $5 \times 10^{8}$ cells $/ \mathrm{ml}$ in drinking water for 18 weeks. Body weights of the groups are shown. B: Representative data of immunohistochemical staining for H2A histone family member $X$ with phosphorylated Ser-139 ( $\gamma H 2 A X)$ from each group are shown. Bars are $200 \mu m$. C: Data are presented as the ratio of positive- $\gamma H 2 A X$ cells relative to all intestinal cells of the luminal surface in each group. Statistical analyses were performed using Tukey's test. 

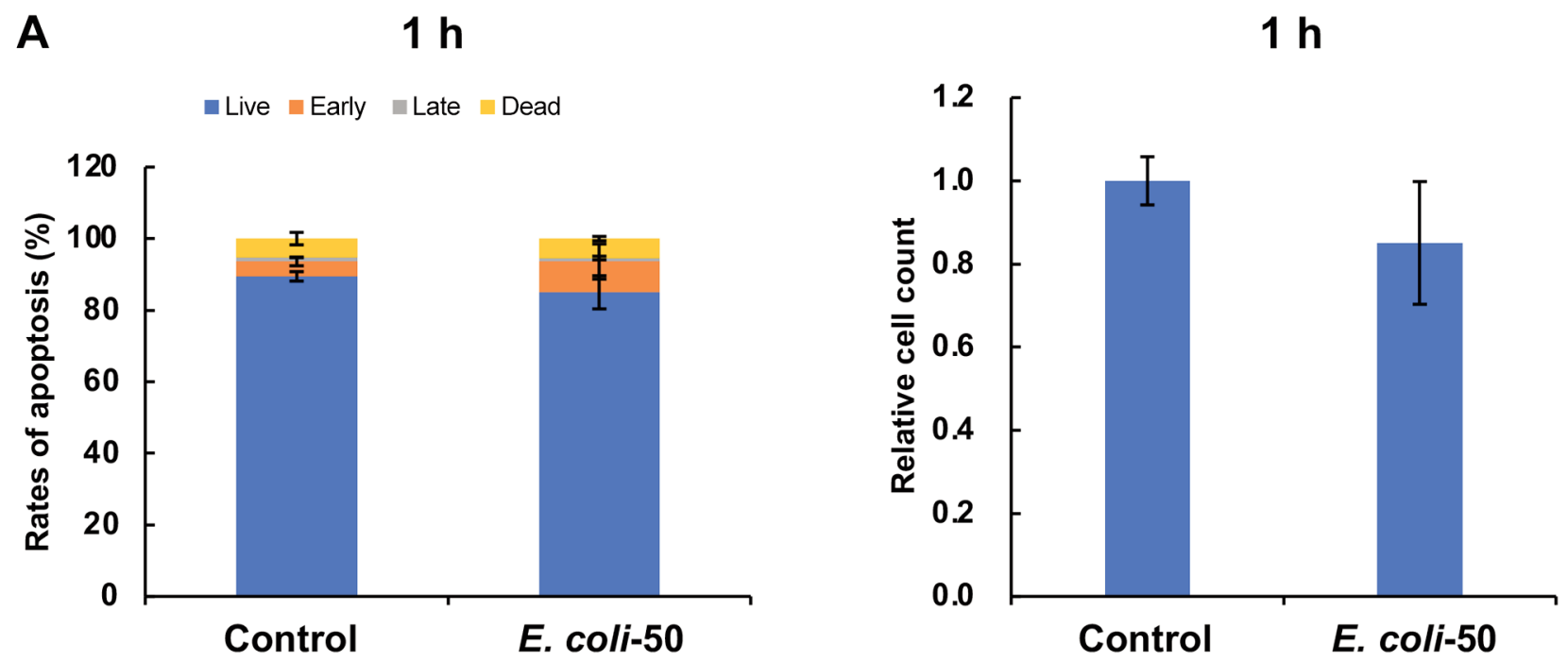

B

$2 \mathrm{~h}$

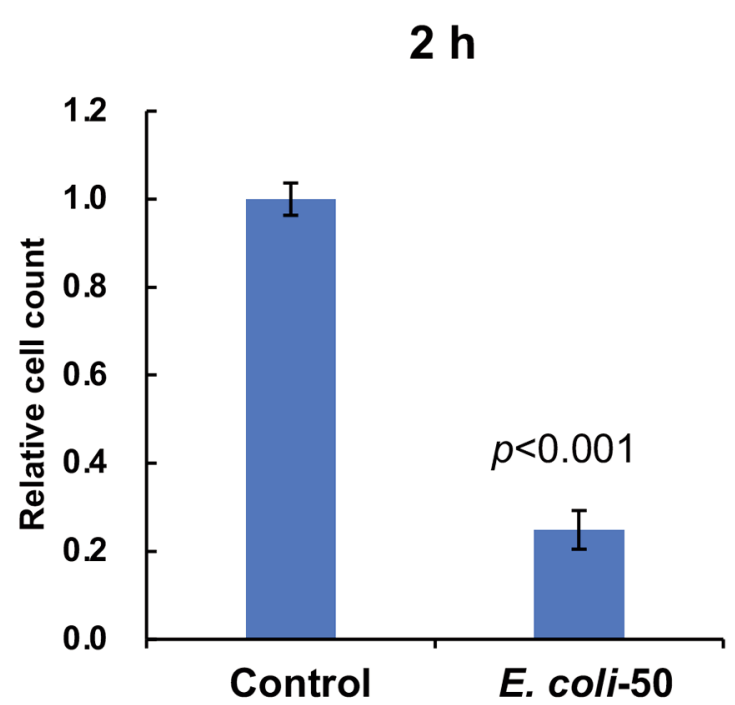

Figure 2. Effects of apoptosis and cell death induced by colibactin. Rat primary colorectal epithelial cells (PriA/MUTO2 cells) were plated in 12-well plates $\left(1 \times 10^{5} \mathrm{cells} /\right.$ well $)$ and treated with or without $\mathrm{clb}^{+}$Escherichia coli isolated from a Japanese patient with colorectal cancer (E. coli50) $\left(O D_{600}=0.5\right)$. After $1 \mathrm{~h}(A)$ or $2 \mathrm{~h}(B)$ treatment, cells were harvested and then stained using annexin-V Alexa Fluor ${ }^{(B)}$ 488/propidium iodide (PI) to evaluate cell status and the ratio of apoptosis (left panel) or counted using a Tali ${ }^{\circledR}$ Image-based cytometer (Right panel). Data are presented as the mean \pm standard deviation. Statistical analyses were performed using Student's t-test. Live: Live cells, annexin-V negative and PI-negative; early: early apoptotic cells, annexin-V positive and PI-negative; late: late apoptotic cells, annexin-V positive and PI-positive.

Apoptosis assay. PriA/MUTO2 cells were plated in 12-well plates $\left(1 \times 10^{5}\right.$ cells/well $)$ and treated with $E$. coli-50 $\left(\mathrm{OD}_{600}=0.5\right)$. Cells were treated with the E. coli strains for 1 or $2 \mathrm{~h}$, harvested and stained using annexin-V Alexa Fluor ${ }^{\circledR} 488$ propidium iodide (PI), as described by the Tali ${ }^{\circledR}$ Apoptosis Kit - Annexin V Alexa Fluor ${ }^{\circledR}$ 488 and PI (Life Technologies Corporation, Carlsbad, CA, USA). Cell counts, death and apoptosis were evaluated using a Tali ${ }^{\circledR}$ Image-based Cytometer (Life Technologies Corporation). Annexin$\mathrm{V}$ positive/PI-negative cells were recognized as early apoptotic cells by cytometry, whereas the annexin V-positive/PI-positive cells were identified as late apoptotic cells; similarly, annexin V-negative/PInegative cells were identified as viable cells and annexin Vnegative/PI-positive cells were identified as dead cells.

Statistical analysis. The results are expressed as means $\pm \mathrm{SD}$ and statistical analyses were performed using Tukey's test or Student's $t$-test. Differences were considered to be statistically significant at $p<0.05$. 


\section{Results}

DNA damage by $\mathrm{clb}^{+}$E. coli-50 in the colorectum of mice. Administration of $E$. coli-50 or E. coli-50/ $\Delta c l b P$ in the drinking water for 18 weeks did not affect body weight (Figure 1A), food intake, daily drinking water intake or clinical symptoms throughout the experimental period in the mice.

We assessed colibactin-induced DNA damage using immunohistochemical staining of $\gamma \mathrm{H} 2 \mathrm{AX}$ in mice colorectal epithelial cells (Figure 1B). In the luminal surface of the rectum, the ratio of $\gamma \mathrm{H} 2 \mathrm{AX}$-positive cells was increased by treatment with E. coli-50 compared to the untreated control mice (Figure 1C). Moreover, the ratio of $\gamma \mathrm{H} 2 \mathrm{AX}$-positive cells in the rectum in the group treated with $E$. coli-50/ $\Delta$ clbP was not increased compared with the controls. In the distal, middle and proximal part of the colon, the ratio of $\gamma \mathrm{H} 2 \mathrm{AX}$ positive cells in the luminal surface did not significantly differ between the groups (Figure 1C).

Cell death induced by colibactin. In vivo experiments showed that DNA damage at the luminal surface of the rectum was increased with $\mathrm{clb}^{+} E$. coli-50 treatment. Thus, we next confirmed the direct interaction of $\mathrm{clb}^{+} E$. coli with normal epithelial cells in vitro. The ratio of apoptosis did not significantly change between $E$. coli-50 cells and untreated cells (Figure 2A, left panel) after the 1-h treatment, whereas there was a slight reduction of the cell count compared to untreated cells (Figure 2A, right panel). E. coli-50 treatment for $2 \mathrm{~h}$ resulted in an increase of apoptotic cell ratio and reduction of the cell count (Figure 2B).

\section{Discussion}

In the present study, we found that treatment of $\mathrm{clb}^{+} E$. coli50 , isolated from a Japanese patient with colorectal cancer, increased DNA damage in the epithelial cells of the luminal surface of mouse rectum. Moreover, in an in vitro setting, $\mathrm{clb}^{+}$E. coli-50 increased the ratio of apoptotic cells and reduced the cell count compared to those of untreated cells.

Turnover of cell division is vigorous in intestinal epithelial cells. This is because intestinal epithelial cells are always exposed to substances that should be excreted, including toxins, and the resultant damaged epithelial cells should be removed from the intestine as fast as possible. Our finding that $\gamma \mathrm{H} 2 \mathrm{AX}$ positive cells were observed in the epithelial cells of the luminal surface of mouse rectum suggests that colibactin derived from E. coli damaged the DNA of epithelial cells by direct contact of $c \mathrm{Cb}^{+} E$. coli with the epithelial cells. If increased DNA damage by colibactin from $E$. coli was observed in the growth zone of intestinal crypts (under $1 / 3$ the area of crypts), it is assumed that organic substances, including colibactin produced by $E$. coli, play an important role in cell damage. However, we did not observe DNA damage by $c l b^{+}$
$E$. coli in the proliferative zone. Further investigation is needed to clarify the reason why $\mathrm{clb}^{+} E$. coli was correlated with colorectal carcinogenesis. One possibility is that retained $\gamma \mathrm{H} 2 \mathrm{AX}$-positive cells in the epithelial cells affected structural maintenance and affected cell growth. In this case, experimental periods greater than we performed in the present study are needed to obtain change in the proliferative zone after treatment with $\mathrm{clb}^{+}$E. coli. Another possibility is involvement of a pathological condition, such as ulcerative colitis, which induces crypt dilation i.e., crypt abscess. In this condition, $\mathrm{clb}^{+}$ $E$. coli might reach the proliferative zone, and play an important role in the development of colorectal cancer.

To observe direct cell damage by $c l b^{+} E$. coli, we performed in vitro assay in which $\mathrm{clb}^{+} E$. coli was able to attach to colorectal epithelial cells. To this end, we derived normal epithelial cells from rat colorectum, and used them instead of cancer cells because the action of colibactin may be different between normal epithelial cells and cancer epithelial cells. As expected, the ratio of apoptosis was increased, and cell counts were reduced by $2 \mathrm{~h}$-treatment with $\mathrm{clb}^{+} E$. coli by more than that of untreated normal epithelial cells. Apoptosis is often observed after DNA damage. Thus, our results also suggest that DNA damage of cells occurs in a short period after $c l b^{+} E$. coli meets epithelial cells.

Another report suggested that $\mathrm{clb}^{+} E$. coli induces cell senescence when compared with colibactin-negative $E$. coli (18). Therefore, colibactin confers resistance to DNA damage-induced cell death in normal colorectal epithelial cells. This might be an additional reason why we observed more $\gamma \mathrm{H} 2 \mathrm{AX}$-positive cells in the $\mathrm{clb}{ }^{+} E$. coli-treated group. In a recent study, colorectal cancer cells were shown to have a mutation signature after long-term exposure to $\mathrm{pks}^{+} E$. coli $(19,20)$. It is assumed that DNA mutation with resistance to apoptosis may play a pivotal role in colorectal carcinogenesis.

In conclusion, we showed that $c l b^{+} E$. coli-50, derived from a patient with colorectal cancer, induced DNA damage in the rectum of mice, possibly by direct interaction between $c l b^{+} E$. coli and normal colorectal epithelial cells. The findings of this study imply that regulation of $\mathrm{clb}^{+} E$. coli infection may lead to the development of preventative methods against colorectal carcinogenesis. Further studies are needed to clarify the detailed mechanism by which colibactin induces colorectal cancer and to develop a useful strategy to prevent colorectal carcinogenesis.

\section{Conflicts of Interest}

The Authors declare no competing interests.

\section{Authors' Contributions}

TN and MM had full access to all of the data in the study and take responsibility for the integrity of the data and the accuracy of the data analysis. Moreover, $\mathrm{K}$ Watanabe, K Wakabayashi and MM 
contributed to the concept, design and drafting of the article. $\mathrm{K}$ Watanabe obtained funding. TN, YT, NM, MK, TH, GF, YY, MS, MK, MT and YI were responsible for acquisition, analysis, or interpretation of data. HS and YT reviewed and supervised this work.

\section{Acknowledgements}

The Authors thank Ms. Ruri Nakanishi and Mr. Naoaki Uchiya, members of the National Cancer Center Research Core Facility, for their expert technical assistance in the experiments.

This work was supported by the Development of Innovative Research on Cancer Therapeutics from Japan Agency for Medical Research and Development (K. Watanabe, 19ck0106475h0001), the Yakult Bio-Science Foundation (K. Watanabe) and SECOM Science and Technology Foundation (K. Watanabe).

\section{References}

1 Shield KD, Freisling H, Boutron-Ruault MC, Touvier M, Marant Micallef C, Jenab M, Deschamps V, Hill C, Ferrari P, Margaritis I, Bray F and Soerjomataram I: New cancer cases attributable to diet among adults aged 30-84 years in France in 2015. Br J Nutr 120(10): 1171-1180, 2018. PMID: 30401003. DOI: 10.1017/ S0007114518002544

2 Feng Q, Liang S, Jia H, Stadlmayr A, Tang L, Lan Z, Zhang D, Xia H, Xu X, Jie Z, Su L, Li X, Li X, Li J, Xiao L, HuberSchönauer U, Niederseer D, Xu X, Al-Aama JY, Yang H, Wang J, Kristiansen K, Arumugam M, Tilg H, Datz C and Wang J: Gut microbiome development along the colorectal adenomacarcinoma sequence. Nat Commun 6: 6528, 2015. PMID: 25758642. DOI: $10.1038 /$ ncomms 7528

3 Liu Y, Ajami NJ, El-Serag HB, Hair C, Graham DY, White DL, Chen L, Wang Z, Plew S, Kramer J, Cole R, Hernaez R, Hou J, Husain N, Jarbrink-Sehgal ME, Kanwal F, Ketwaroo G, Natarajan Y, Shah R, Velez M, Mallepally N, Petrosino JF and Jiao L: Dietary quality and the colonic mucosa-associated gut microbiome in humans. Am J Clin Nutr 110(3): 701-712, 2019. PMID: 31291462. DOI: 10.1093/ajen/nqz139

4 Yachida S, Mizutani S, Shiroma H, Shiba S, Nakajima T, Sakamoto T, Watanabe H, Masuda K, Nishimoto Y, Kubo M, Hosoda F, Rokutan H, Matsumoto M, Takamaru H, Yamada M, Matsuda T, Iwasaki M, Yamaji T, Yachida T, Soga T, Kurokawa K, Toyoda A, Ogura Y, Hayashi T, Hatakeyama M, Nakagama H, Saito Y, Fukuda S, Shibata T and Yamada T: Metagenomic and metabolomic analyses reveal distinct stage-specific phenotypes of the gut microbiota in colorectal cancer. Nat Med 25(6): 968-976, 2019. PMID: 31171880. DOI: 10.1038/s41591019-0458-7

5 Faïs T, Delmas J, Barnich N, Bonnet R and Dalmasso G: Colibactin: More than a new bacterial toxin. Toxins (Basel) 10(4): 151, 2018. PMID: 29642622. DOI: 10.3390/toxins 10040151

6 Deane C: Colibactin comes to light. Nat Chem Biol 15(10): 933, 2019. PMID: 31541229. DOI: 10.1038/s41589-019-0373-8

7 Tsunematsu Y, Hosomi K, Kunisawa J, Sato M, Shibuya N, Saito E, Murakami H, Yoshikawa Y, Iwashita Y, Miyoshi N, Mutoh M, Ishikawa $H$, Sugimura $H$, Miyachi $M$, Wakabayashi $K$ and Watanabe K: Mother-to-infant transmission of the carcinogenic colibactin-producing bacteria. BMC Microbiol 21(1): 235, 2021. PMID: 34429063. DOI: 10.1186/s12866-021-02292-1
8 Nougayrède JP, Homburg S, Taieb F, Boury M, Brzuszkiewicz E, Gottschalk G, Buchrieser C, Hacker J, Dobrindt U and Oswald E: Escherichia coli induces DNA double-strand breaks in eukaryotic cells. Science 313(5788): 848-851, 2006. PMID: 16902142. DOI: $10.1126 /$ science. 1127059

9 Arthur JC, Perez-Chanona E, Mühlbauer M, Tomkovich S, Uronis JM, Fan TJ, Campbell BJ, Abujamel T, Dogan B, Rogers AB, Rhodes JM, Stintzi A, Simpson KW, Hansen JJ, Keku TO, Fodor AA and Jobin C: Intestinal inflammation targets cancerinducing activity of the microbiota. Science 338(6103): 120-123, 2012. PMID: 22903521. DOI: 10.1126/science. 1224820

10 Cuevas-Ramos G, Petit CR, Marcq I, Boury M, Oswald E and Nougayrède JP: Escherichia coli induces DNA damage in vivo and triggers genomic instability in mammalian cells. Proc Natl Acad Sci U.S.A. 107(25): 11537-11542, 2010. PMID: 20534522. DOI: $10.1073 /$ pnas.1001261107

11 Arthur JC, Gharaibeh RZ, Mühlbauer M, Perez-Chanona E, Uronis JM, McCafferty J, Fodor AA and Jobin C: Microbial genomic analysis reveals the essential role of inflammation in bacteria-induced colorectal cancer. Nat Commun 5: 4724, 2014. PMID: 25182170. DOI: 10.1038/ncomms5724

12 Zhou T, Hirayama Y, Tsunematsu Y, Suzuki N, Tanaka S, Uchiyama N, Goda Y, Yoshikawa Y, Iwashita Y, Sato M, Miyoshi N, Mutoh M, Ishikawa H, Sugimura H, Wakabayashi K and Watanabe K: Isolation of new colibactin metabolites from wild-type Escherichia coli and in situ trapping of a mature colibactin derivative. J Am Chem Soc 143(14): 5526-5533, 2021. PMID: 33787233. DOI: 10.1021/jacs.1c01495

13 Wilson MR, Jiang Y, Villalta PW, Stornetta A, Boudreau PD, Carrá A, Brennan CA, Chun E, Ngo L, Samson LD, Engelward BP, Garrett WS, Balbo S and Balskus EP: The human gut bacterial genotoxin colibactin alkylates DNA. Science 363(6428): eaar7785, 2019. PMID: 30765538. DOI: 10.1126/ science.aar7785

14 Hirayama Y, Tsunematsu Y, Yoshikawa Y, Tamafune R, Matsuzaki N, Iwashita Y, Ohnishi I, Tanioka F, Sato M, Miyoshi $\mathrm{N}$, Mutoh M, Ishikawa H, Sugimura H, Wakabayashi K and Watanabe K: Activity-based probe for screening of highcolibactin producers from clinical samples. Org Lett 21(12): 4490-4494, 2019. PMID: 31192617. DOI: 10.1021/acs.orglett. $9 \mathrm{~b} 01345$

15 Kawanishi M, Shimohara C, Oda Y, Hisatomi Y, Tsunematsu Y, Sato M, Hirayama Y, Miyoshi N, Iwashita Y, Yoshikawa Y, Sugimura H, Mutoh M, Ishikawa H, Wakabayashi K, Yagi T and Watanabe K: Genotyping of a gene cluster for production of colibactin and in vitro genotoxicity analysis of Escherichia coli strains obtained from the Japan Collection of Microorganisms. Genes Environ 42: 12, 2020. PMID: 32175032. DOI: 10.1186/ s41021-020-00149-Z

16 Yoshikawa Y, Tsunematsu Y, Matsuzaki N, Hirayama Y, Higashiguchi F, Sato M, Iwashita Y, Miyoshi N, Mutoh M, Ishikawa $\mathrm{H}$, Sugimura $\mathrm{H}$, Wakabayashi $\mathrm{K}$ and Watanabe $\mathrm{K}$ : Characterization of colibactin-producing Escherichia coli isolated from Japanese patients with colorectal cancer. Jpn J Infect Dis 73(6): 437-442, 2020. PMID: 32475872. DOI: 10.7883/yoken.JJID.2020.066

17 Kawanishi M, Hisatomi Y, Oda Y, Shimohara C, Tsunematsu Y, Sato M, Hirayama Y, Miyoshi N, Iwashita Y, Yoshikawa Y, Sugimura H, Mutoh M, Ishikawa H, Wakabayashi K, Yagi T and Watanabe K: In vitro genotoxicity analyses of colibactin- 
producing E. coli isolated from a Japanese colorectal cancer patient. J Toxicol Sci 44(12): 871-876, 2019. PMID: 31813906. DOI: $10.2131 /$ jts. 44.871

18 Cougnoux A, Dalmasso G, Martinez R, Buc E, Delmas J, Gibold L, Sauvanet P, Darcha C, Déchelotte P, Bonnet M, Pezet D, Wodrich H, Darfeuille-Michaud A and Bonnet R: Bacterial genotoxin colibactin promotes colon tumour growth by inducing a senescence-associated secretory phenotype. Gut 63(12): 19321942, 2014. PMID: 24658599. DOI: 10.1136/gutjnl-2013-305257

19 Pleguezuelos-Manzano C, Puschhof J, Rosendahl Huber A, van Hoeck A, Wood HM, Nomburg J, Gurjao C, Manders F, Dalmasso G, Stege PB, Paganelli FL, Geurts MH, Beumer J, Mizutani T, Miao Y, van der Linden R, van der Elst S, Genomics England Research Consortium., Garcia KC, Top J, Willems RJL, Giannakis M, Bonnet R, Quirke P, Meyerson M, Cuppen E, van Boxtel $\mathrm{R}$ and Clevers $\mathrm{H}$ : Mutational signature in colorectal cancer caused by genotoxic pks $^{+}$E. coli. Nature 580(7802): 269273, 2020. PMID: 32106218. DOI: 10.1038/s41586-020-2080-8
20 Dziubańska-Kusibab PJ, Berger H, Battistini F, Bouwman BAM, Iftekhar A, Katainen R, Cajuso T, Crosetto N, Orozco M, Aaltonen LA and Meyer TF: Colibactin DNA-damage signature indicates mutational impact in colorectal cancer. Nat Med 26(7): 1063-1069, 2020. PMID: 32483361. DOI: 10.1038/s41591-0200908-2
Received December 3, 2021

Revised December 20, 2021

Accepted December 21, 2021 